\title{
Euskalkultura.com: euskal diasporaren hedabidea
}

\author{
Euskalkultura.com: Medio de la diáspora vasca \\ Euskalkultura: Basque diaspora media
}

\author{
Maialen Goirizelaia ${ }^{\star}$, Leire Iturregui \\ Universidad del País Vasco/Euskal Herriko Unibertsitatea (UPV/EHU)
}

\begin{abstract}
LABURPENA: Euskal diasporak Euskal Herriarekin duen komunikazioa ikertzen duen tesi lan baten testuinguruan, Euskal Herria eta euskal diasporaren kasuan «diaspora medio» baten ezaugarriak betetzen dituen hedabide bakarra identifikatu da: Euskalkultura.com. Artikulu honetan 'diaspora medio' horren azterketa proposatzen da eta horretarako, bere sorrera eta eboluzioa azaltzen dira, eta 2015 eta 2018 urte bitartean argitaratu dituen albisteen kategorizazioa egin da, non ikusi den gehienbat kulturari buruzko albisteak publikatzen dituztela. Azkenik, Estatu Batuetako euskaldunek egiten duten medioaren kontsumoa analizatu da inkesta baten bidez. Emaitzen artean aipagarria da, nahiz eta, batez ere, harreman kulturalak estutu nahi izan, beste era batetako komunikazioa eta harremanak ere garatu nahi dituztela eta, adibidez, hezkuntza eta enpresa alorrean.
\end{abstract}

GAKO HITZAK: Diaspora; euskal diaspora; hedabide digitalak; diaspora hedabidea

ABSTRACT: In the framework of a thesis that studies the communication between the Basque diaspora and the Basque Country, we have found a media that fulfill the characteristics that a «diaspora media» have: Euskalkultura.com. In this work, we aim to study the creation and evolution of this «diasporic media», analyzing for that the articles published during 2015-2018, in which we could see that the majority of them are about Basque culture; the consumption that the Basques living in the United States do of this media, where we could appreciate that even though they mainly want to maintain cultural relations, they also want to have other kind of relations with the Basque Country, such as educational and business relations.

KEYWORDS: Diaspora; Basque diaspora; digital media; diasporic media

\footnotetext{
* Harremanetan jartzeko / Corresponding author: Maialen Goirizelaia. Universidad del País Vasco (UPV/EHU). Facultad de Ciencias Sociales y de la Comunicación. Campus de Bizkaia. Barrio Sarriena s/n. 48940 Leioa - maialen.goirizelaia@ehu.eus - https://orcid.org/00000001-9478-1503

Nola aipatu / How to cite: Goirizelaia, Maialen; Iturregui, Leire (2019). "Euskalkultura.com: euskal diasporaren hedabidea»; Zer, 24(46), 165-185. (https://doi.org/10.1387//2er.20403).

Jasoa: 20 azaroa, 2018; Onartua: 25 otsaila, 2019.

ISSN 1137-1102 - eISSN 1989-631X / (C) 2019 UPV/EHU

(c) (i) Obra hau Creative Commons Atribución 4.0 Internacional-en

lizentziapean dago
} 


\section{Sarrera}

Euskal Herriak 3.150.000 pertsonako populazioa dauka. Ez da erraza sorterritik kanpo bizi diren euskaldunen kopuru zehatza izatea, hala ere, estimazioek diote, Euskal Herritik kanpo bizi diren euskaldunak 8 milioi inguru izan daitezkeela. Euskaldun horiek munduko hainbat lekutan bizi dira, eta herrialde horietara joan izanaren arrazoiak eta garaiak ere, ugari dira, hala nola, Euskal Herriko oinordekotza sistema; lan bila atzerrira joatea, soldaduska ekiditea; gerra karlista edota gudu zibila (Douglass, 1986; Santiso González, 1998).

Kanpoan bizi diren euskaldun horien artean badaude Europako immigrazio olatua izan zenean, beste hainbat europarrekin batera, Ameriketako Estatu Batuetara joandakoak, gehienak, artzain, lorezain edota hezkuntzarik beharrezkoa ez zen lanak egitera joan ziren. Estatu Batuetan badaude, baita ere, xx. mende hasieratik pilotari joandakoak eta Estatu Batuek eskaintzen duten garapen profesional eta ekonomikoak erakarriak. Beste alde batetik, XIX. mende erdi eta amaieran eta Espainiako Gerra Zibilean Hego Ameriketako hainbat herrialdetara joandakoak daude. Asiako herrialdeetan ere posible da euskaldunik topatzea; eta, amaitzeko, egun diaspora 2.0 edo migrazio berriak deritzenak daude: garapen profesionalaren bila Europako beste herrialde batzuetara joandako euskaldunak.

Internetek, sare sozialek eta medio digitalek asko erraztu dute orokorrean migrazio talde eta euren jatorrizko herrialdearen arteko komunikazioa, baita eguneratuta egon eta momentuko albisteak jasotzeko ahalmena ere. Euskal diasporaren kasuan posible da Euskal Herriko albisteak irakurtzea, sare sozial edo medio digitalei esker. Amezagaren hitzetan: «Informazio eta komunikazio teknologia berriek, beraz, aukera ezberdinak ematen dizkiete diasporako kideei beren euskaltasuna etengabe berreraikitzeko. Batez ere, internet eta satelite bidezko telebistak" (2004: 128).

Gainera, euskal diaspora oso presente dago sare sozialetan, 2010 urtean Pedro Oiarzabalek euskal diasporako instituzioek sare sozialetara egin zuten saltoa ikertu zuen eta etorkizunera begira, euskal diaspora digitala gero eta ugariagoa izango zela esaten zuen:

"Although it is not wise to prognosticate about any future trends of the Basque diaspora presence on the Web, evidence shows an increasing tendency for articulating an online presence. For example, from the beginning of 2004 to the end of 2005, 13 new diaspora institutional web sites were created, and from October 2005 to June 2007 another 30, the majority of which are Basque clubs, or Euskal etxeak, and mainly from Argentina» (Oiarzabal, 2010: 339) 
Aurreikusi zuen hori horrela da eta egun, munduan zehar dauden ehunka euskal etxe, elkarte, dantza talde eta diasporako indibiduo presente daude Facebook-en eta beste sare sozial batzuetan, kasurako, Instagram-en.

Sareak ematen dituen abantailez baliatuz badago espresuki diasporako kideei zuzenduriko hedabide bat: Euskalkultura.com. Ikerketa honetan proposatzen da Euskalkultura.com, 1998an urtean sortua, jatorrizko herrialdetik euskal diasporak duen «diasporic media» bakarra dela:

«Guk geure burua diasporakotzat daukagu. Guk argi daukagu hanka bat daukagula hemen eta beste bat kanpoan. Diaspora gu gara. 30 urte dira diaspora barrutik bizitzen dugula. Jendearen arazoak saiatzen gara argitzen etab. Jendea harremanetan jartzen...baina gu diasporak sortutako produktu bat gara. Seguruenik Euskal Herrian dagoen bakarra.» (Joseba Etxarri, Euskalkultura.com-eko zuzendaria, komunikazio pertsonala, 2017 urteko urria)

\section{Gaiaren egoera}

\subsection{Diaspora MEDioA: identitATEA MANTENDU ETA SORTZEKO BIDE}

Espainiako estatuan, lehen «Migrant minority media»-k (migratzaileengandik eta hauen errealitatetik hurbil dauden eta zerbitzu on bat eskaintzen duten komunikabideak (Navaz \& Ferrer, 2012)) 1990 erdialdean agertu ziren (Navaz eta Ferrer 2012). Ikerketa horren arabera, 2004 urtetik aurrera diasporara zuzendutako aldizkari, egunkari, irrati, telebista kate eta webguneen kopurua asko hasi da eta 2008 urte amaierarako, euren datu basean Espainian 300 «Migrant minority media» zeuzkaten. Dallemagne, Echevarría Vecino eta Ferrández Ferrerek ere Espainiak gutxiengoentzako sorturiko bi medioen azterketa egiten dute: Latino eta Sí se puede. Bi argitalpenak Espainian migratzaileentzako dauden argitalpenen artean lehenak dira (ACPI, 2008), 430.900 eta 231.600 irakurlerekin astero. Diaspora medioa kontzeptua ikertzen dutenen artean Bozdag, Hepp eta Suna-ren (2012) lana dago. Autore horien hitzetan diaspora hedabideak dira «the 'focus' of communicative networking among migrants», diaspora komunitateentzako garrantzitsuak diren gaiei buruz hitz egiten dutenak eta migratzaileentzako eta migratzaileen eskutik sortu diren hedabideak (2012: 97). Horiez gain, Ogunyemik (2015) kontzeptuaren berrikusketa egiten du eta bere liburuan hainbat kasu azterketa daude diaspora kazetaritzari buruz zeintzuk gehienetan diasporatik idatziak diren. Karim-ek ere (2003) diaspora kazetaritza aztertzen du, eta nola medio hauek maila lokal eta transnazionalean harremanak sortzeko balio duten. Georgiouk (2005) 
Europan dauden diaspora medioak ikertu ditu eta berak ere dio, hedabide hauen ekarpena nabaria dela multikulturala den Europa baten ideian eta komunitate transnazionaletan parte hartzeko (edo ez hartzeko) (2005: 1). Esaten du diaspora hedabide guztiak dauzkatela gauza komun batzuk: "All address particular ethnic, linguistic and/or religious groups that live within broader and diverse multicultural societies» (Georgiou 2005: 482). Retisek (2011) teknologia berriek, internetek eta komunikazio birtualaren berehalakotasunak komunikazio transnazionala sortzen duela dio eta horrek, identitate indibidual eta kolektiboen arteko sinergia historiko, sozial eta kulturalak sortzeko aukera ematen duela.

Diaspora hedabideak eta identitatearen arteko harremana ikertzen dutenen artean daude Sinclair eta Smets (2014). Satelite bidezko telebista kurdoa aztertzen dute (Med-TV, Medya-TV and Roj-TV) eta honen eragina "Kontzientzia Kurdoaren konstrukzioan» (2014: 3). Leurs eta Ponzanesi-k (2010) Andersonen «Komunitate imajinatuei» (1993) buruz hitz egiten dute eta migranteen talde gazteek diaspora digitala imajinatzeko dituzten taktikak aztertzen dituzte. Smets, Meers, Vande Winkel eta Van Bauwel-ek (2011) Europako diaspora medioen kasu azterketa egiten dute eta esaten dute gai hau interes handia irabazten ari dela mundu akademikoan. Ikertzen dituzten kasuen artean, Turkiarren pelikulak aztertzen dituzte diaspora medio bezala Belgikan. Georgiouk ere era digitaleko diasporak ikasi ditu, eta Europako hirietan bizi diren Arabiar diasporekin lan egin du: Londres, Madril eta Nicosian (2013:81). Amaitzeko, Agirreazkuenagak eta Larrondok, Bilbon sortutako Candela irratiaren azterketa egiten dute, eta honen eragina euskal-latino identitatearen sorreran.

Euskal diasporarekin komunikatzerakoan komunikabideak, ekimen instituzionalak eta diasporako kideen iniziatibak dira nagusi. Ikerketa gutxi egin izan da diaspora medioei buruz (Ogunyemi, 2015) eta euskal kasuan, are gutxiago. Euskal diasporara zuzendutako komunikabideen azterketa egin dutenen artean Amezagak (2004) zioen satelite bidezko telebistak euskal nortasunaren garapenean lagundu zezakeela, bai Euskal Herrian zirenei zein diasporako kideei. Peñafiel, Casado, Fernandez de Arroyabe eta Gómezek ere (2008) egin zuten Galeuscaren (Galiziako Telebistak, Euskal Telebistak eta Catalyunako Telebistak euren diaspora taldeei zuzentzeko sortu zuten nazioarteko katea) azterketa bat. Ekimen instituzionalei dagokionez, Eusko Jaurlaritzak argitaratzen dituen Kanpo Harremanetarako Estrategia aztertzen duten liburuak daude, eta, amaitzeko, atzerrian bizi ziren euskaldunak idatzitako egunkari eta aldizkariei dagokionean, aldizkari guzti edo gehienak daude eskuragarri Eusko Jaurlaritzaren lanari esker Urazandi digitalean ${ }^{1}$.

\footnotetext{
1 Urazandi digitalaren webgunea: http://urazandi.euskaletxeak.net/default.html\#
} 
Euskalkultura.com da, batez ere, atzerrian bizi diren euskaldunak publiko moduan dituen hedabidea. Argitaratzen diren albisteak mundu osoan zehar irakurtzen dira eta Euskal Herriaren eta kanpoan diren euskaldunen arteko komunikazioan laguntzen du. Egun arte, ez da ikerketarik topatu Euskalkultura.com diaspora medioari buruz eta are gutxiago esparru akademikoan.

\section{Marko teorikoa}

\subsection{Diaspora Hedabidea}

Georgiouk (2005) dio diaspora hedabideek tamaina, profesionaltasun, arrakasta eta bizitza desberdina dutela baina badauzkatela komunak diren gauza batzuk, adibidez, kultura anitzak dituzten gizarteetan eta euren mugetatik haratago bizi direnen partikulartasun etnikoa, linguistikoa eta erlijiosoa. Diasporak beste talde baten parte direla sentitzen duten talde gutxituak dira eta diaspora hedabideek audientzia horiek lortu behar dituzte. Audientzia gutxitu hauek jatorrizko herrialdeko informazioa jaso nahi dute, tarte diasporikoak zabaldu nahi dituzte: «As well as from the national and local context where they are embedded and the analytical articulation» (Georigiou 2005: 9).

Karimek (2003) dio diaspora hedabideak lotura transnazionalak indartzeko eta urrun dauden pertsonen identitate eta kultura nazional, erlijioso eta etnikoak eusteko bide berriak direla. Ogunyemik (2015:3) beste autore batzuk diaspora hedabidearen kontzeptuari buruz esaten dutena biltzen du. Nacifyk (2003) diaspora hedabideak jatorrizko herrialdetik inportatu eta bizi diren herrialdean produzituko diren programak direla planteatzen du. Georgiouk (2006) hedabide bat baino gehiago direla proposatzen du eta horrekin bat eginik Yinek (2013), Johnsonek (2000), Jeffresek (1999) eta Zhand eta Haoek (1999) hedabide hauek identitatea eta azpitaldeak batzeko balio dutela baieztatzen dute.

Fazal eta Tsagarousianouek (2002) diote «the diasporic media space» direla bai jatorriko herritik zein orain bizi diren herrian «migrant minority media» deitzen direnak, nazioarteko albiste kateak, eta munduko edozein partetik lortu daitezken sareko iturriak (Navaz \& Ferrer 2012: 4).

Diasporarekin komunikatzeko balio duten hedabideei buruz, Amezagak (2004) dio satelite bidezko telebistei esker komunikazio bidea zabaltzen dela eta eremu nazionalak, pannazionalak, geoestrategikoak, linguistikoak, diasporikoak eta globalak daudela. Eremu diasporiko bezala definitzen ditu gobernuek zein diasporako kideek harremana mantentzeko erabilitako bideak. 


\subsection{EUSKAL DIASPORA}

Euskal diaspora definitzerakoan nahitaezkoa da hainbat lurraldetan eta garai ezberdinetan izan diren euskal komunitateen azterketa egitea, hartara ikusi ahal izateko zein neurritan betetzen dituzten komunitate horiek jatorri bereko gizatalde bat diasporatzat hartzeko adituek ezinbestekotzat hartzen dituzten ezaugarriak. Aipatutako diaspora-kontzeptuak azken hamarkadetan izandako bilakaeraren erakusgarri da, kasurako, Ameriketara joandako euskaldunen seme-alabek, ilobek eta birbilobek euskal izaeraz edo euskalduntasunaz egun duten ikuspegi zeharo ezberdina. xx. mendearen erdialdean ia inork ez zuen diaspora bateko kide izan nahi, horrek zuen konnotazio negatiboa zela-eta. Gauzak aldatu egin dira, ordea, eta Lee Hansenek The Problem of the Third generation liburuan esaten zuena ere gertatu da euskal diasporaren kasuan: bigarren belaunaldiak ahaztu nahi izan zuena hirugarrenak gogoratu egin nahi du (Marcus Lee Hansen, 1938).

Hori dela eta, euskal diaspora definitzerakoan arazoak izan ditugu, izan ere, Totoricaguenak bere tesian dioen moduan: «The Basque collectivities do exhibit a transnational diaspora mentality though they are not likely to use the «diaspora» terminology» (2000:229). Ez da terminologia hori erabili, eta horren arrazoia, arestian ikusi dugun moduan, terminoak konnotazio negatiboa zuelako izan zitekeen. Hori dela eta, euskal diaspora erabili ordez, euskal migrazioa erabili izan da. Hala ere, berak bai defendatzen du euskal diaspora bat dagoela (Totoricaguena, 2000).

Honen harira, Óscar Álvarez Gila, Alberto Angulo Morales eta José Bernardo Marcilesek 2007 urteko Euskal Kolektibitateen Mundu Batzarrean ${ }^{2}$ aurkeztu zuten lanean esandakoari erreferentzia egiten zioten. Euren hitzetan gero eta ikerketa gehiago ari ziren egiten gaiaren inguruan eta terminologia ere aldatzen ari zen. Horrela, esaten zuten jada ez dela lehen egiten zen moduan euskal emigranteei buruz hitz egiten, horren ordez, diaspora edo zortzigarren probintzia bezalako hitzak erabiltzen hasi zirela aipatzen zuten (Goirizelaia eta Iturregui, 2018: 4).

Ikus daiteke, beraz, orokorrean diaspora hitzarekin gertatu den moduan, euskal diasporarekin ere konnotazioa aldatzen joan den heinean, erabilera ere gehiagotzen joan dela. Totoricaguenarekin (2000) eta Oiarzabalekin (2010) bat gatoz eta guk ere proposatzen dugu badagoela euskal diaspora bat. Nahiz eta hasiera batean ez zen hitz hori erabiltzen, egun hitzaren erabilera komuna da bai esparru akademikoan

\footnotetext{
21995 urtean hasita eta lau urtero Kanpo Harremanetarako Idazkaritza Nagusiko parte den Euskal Etxe eta Kanpoan bizi diren euskaldunekin harremanaz arduratzen den Zuzendaritzak Euskal Kolektibitateen Mundu Biltzarra antolatzen du. Biltzar honetan munduan zehar dauden euskaldunak eta euskal etxeetako ordezkariak biltzen dira hiru-lau egunez euren artean ezagutu, Jaurlaritzarekin harremana indartu eta diasporarekin dagoen komunikazioa eta harremanari buruz hitz egiteko.
} 
zein profesionalean ere. Horregatik, euskal diaspora dagoela esaten dugu eta euskal diasporako kide izango dira ikerketa lan honetan Euskal Herritik kanpo bizi arren (gutxienez urte bat (Kennyk 2013: 95)), euskal jatorria eta identitatea izan eta jatorrizko herriarekin lotura bat duten horiek.

\section{Metodologia}

Ikerketa lan honek hiru helburu ditu: Euskalkultura.com-en sorrera eta eboluzioa ezagutzea, argitaratzen dituen albisteen kategorizazioa egitea eta, Estatu Batuetan bizi diren euskaldunek jaso nahi dituzten albisteak zeintzuk diren ezagutzea. Horrela, ikusi ahal izateko, argitaratzen diren albisteak eta jaso nahi dituztenak akorde doazen, edo bestelako planteamendu bat beharrezkoa den. Helburu horiek lortzeko erabilitako metodologia teknika kuantitatibo eta kualitatiboetan oinarritu da. Alde batetik, Euskalkultura.com medioaren sorrera eta eboluzioa ezagutzeko medioaren zuzendariarekin sakoneko elkarrizketa egin da. Euskalkultura.com medioa da diasporako kideei buruz informazio eguneratua ematen duen hedabide bakarrenetarikoa. Horregatik, honen sorreratik bere zuzendaritzan egon den Joseba Etxarrirekin elkarrizketa egitea beharrezkoa zen. Horrez gain, beste sakoneko elkarrizketa bat ere egin da 1999 urtetik 2009 urtera Kanpoan den euskal komunitatearentzako eta euskal etxeentzako zuzendaria izan den Josu Legarretarekin, zeinek Euskal Herriaren eta euskal diasporaren arteko komunikazioa nola garatu den ezagutzen lagundu zigun.

Zuzendaritza hau Eusko Jaurlaritzako Lehendakaritzaren barruan dagoen Kanpo Harremanetarako Idazkaritza Nagusian kokatzen da. Bertan kokatzen dira, baita ere, Kanpo Harremanei buruz arduratzen den saila, Europako gaie buruz arduratzen dena eta Kanpoan bizi diren euskaldunei eta euskal etxeei buruz arduratzen dena. Azken horretan Euskal Herritik arrazoi desberdinengatik alde egin behar izan dutenekin eta antolatuta dauden diaspora eta euskal etxeekin harremana koordinatzen da zein, maiatzaren 27ko 8/1994 legeak arautzen duen. Gure ikerketa gaia guztiz lotuta dago kanpoan bizi diren euskaldunekin dagoen harremanean, eta, beraz, horiekin komunikatzeko ekimen asko Lehendakaritzako zuzendaritza honetatik jarri direnez martxan, beharrezkoa ikusten genuen Zuzendaritza horretako zuzendariren batekin hitz egitea.

Sakoneko elkarrizketa biak aurrez aurre egin dira, grabatu egin dira eta iraupena (gutxienez) bi ordukoa izan da. Bien edukia transkribatua izan da.

Bestalde, lan honen lehen autoreak hiru hilabeteko ikerketa egonaldia egin zuen Idahon, egonaldi horretan sakoneko elkarrizketak egin zituen Idaho eta Nevadako euskaldunekin. Elkarrizketa horietan Euskal Herriko jendearekin, familiarekin eta herriko berriak ezagutzeko dituzten komunikazio ohiturak zeintzuk diren eza- 
gutu nahi izan du autoreak. Elkarrizketa guzti horiek Boiseko Euskal etxean, bertako euskal jatetxeetan, Euskal Museoan edota diasporako kideen etxeetan egin dira. Grabatu egin dira eta gero autoreak transkribatu egin ditu. Elkarrizketa horien iraupena 45 minututik 3 ordura artekoa izan da. Sakoneko elkarrizketa horien emaitzak ere erabili dira lan honen helburuak lortzeko.

Horrez gain, 2015-2018 urteen artean Euskalkultura.com-ek argitaratzen dituen albisteen analisia egin da, guztira 473 albiste aztertu direlarik. Albisteak aztertu eta kategoria desberdinetan sakabanatu dira gaia eta protagonistaren arabera. Gaiaren arabera, kultura, politika, euskal etxeak, jaialdiak, gizartea, historia, diru laguntzak, edukazioa, enpresa eta harremanei buruzko albisteak kategorizatu dira. Hala ere, emaitzetan ez dira kategoria guztiak jarri, batzuen portzentajea baxua zelako, adibidez, politika, gizartea, historia, diru laguntzak eta enpresa gaiekin lotutakoenak. Azkenik, albisteen protagonistei dagokionez, diasporako kideak, Eusko Jaurlaritzako ordezkariak, eta Euskal Herriko herritarrak diren aztertu da.

Amaitzeko, 2018 urteko maiatzean lanaren autoreek inkesta bat zabaldu dute Estatu Batuetan bizi diren euskaldunen artean, eta eskuragarri egon da Estatu Batuetan dauden Euskal etxeetako Facebook orrietan, diasporako kideen sare sozialetan eta Hella Basque eta $A$ Basque in Boise blog-etan. Inkesta horretan komunikabideen kontsumoa eta komunikazio ohiturei buruz galdetzen zitzaien diasporako kideei. Guztira 47 galdera egin zitzaizkien eta horietako 2 erabili dira lan hau egiteko. Bi galdera horiek ziren: «Irakurtzen duzu Euskalkultura.com?» eta «Zein esparru uste duzu hobetu beharko zela Euskal Herriko instituzioen eta kanpoan bizi diren euskaldunen artean?».

Bigarren galdera horren erantzunen artean daude kultura, enpresa, hezkuntza, politika eta «ez dakit» aukerak. Hezkuntzaren barruan egongo lirateke euskara klaseei buruzko albisteak; Euskal Herriko historiari buruzkoak; ikastaroak; baina, baita ere, Estatu Batuetako eta Euskal Herriko Unibertsitatearen arteko harremanak edota ikastola eta eskolen arteko harremanak. Enpresaren atalean enpresen arteko harremanak edota kanpoan bizi diren euskaldunen eta bertako enpresen arteko mobilizazio eta sarean erraztasuna lortzea erraztuko duten albisteak egongo dira.

Guztira 423 erantzun lortu ziren, Estatu Batuetako hainbat Estatutatik jasoak, horien artean, besteak beste, Massachusetts, New York, Connecticut, Arizona, Idaho, Nevada, California, Florida, Washington, Noth Carolina, Oregon, Texas eta Nevada daude; adin ezberdinetako kideek erantzun dute, eta Euskal Herriarekin duten lotura ere, desberdina da, batzuk lehen belaunaldikoak dira, beste batzuk bigarren belaunaldikoak eta beste batzuen harremana oraindik urrunagokoa da.

Kontuan izan behar da ikerketa honek baduela ahulezia bat eta datuak aztertzerakoan eta emaitzak interpretatzerakoan hori presente eduki behar dela. 
Inkesta internet erabiltzen duen komunitateko parte batek erantzun du, eta kontziente gara, euskal diasporako kide guztiek ez dutela internet erabiltzen, alde batetik, eta bestetik, inkesta hau Estatu Batuetako euskaldunen artean bakarrik zabaldu zela, eta beraz, munduan dauden beste euskal komunitate batzuetako kideak, kasurako, Argentina edota Europako beste herrialde batzuetakoak, erantzun hauetatik kanpo gelditzen direla.

\section{Emaitzak}

Euskal Herriaren historian izan dira kanpoan bizi diren euskaldunekin komunikatzeko hainbat bide edota medio. Horien artean daude komunikabideen saiakerak, ekimen instituzionalak eta diasporak berak sortutako iniziatibak.

Euskal Herritik bideratutako komunikabideen kasuan daude EiTB telebista kate publikoaren EtbSat edo CanalVasco kateak; irratiari dagokionez, kasurako, Etxarrik 11 urtez zuzendu zuen Radio Euskadiko Vascos en América saioa edota 8 Probintziak Basque diaspora radio program; eta egunkari eta aldizkariei dagokionez adibidez, Herria astekaria eta egunkari desberdinek argitaratzen dituzten diasporari buruzko artikuluak etab.

Horrez gain, EiTB-ren parte dira «A Basque in Boise» eta «Basque Identity 2.0» blog-ak zeintzuk diasporarekin elkarlanean Euskal Herriko zein euskal diasporako kideei buruz idazten duten.

Ekimen instituzionalei dagokionez, badira diasporako kideei zuzenduriko buletin edo newsletter-ak, kasurako, Eusko Jaurlaritzako Kanpo Harremanetarako Idazkaritza nagusiak astero zabaltzen duen Euskaletxeak newsletter-a edota Estatu Batuetako ordezkaritzak argitaratzen zuena.

Amaitzeko, kanpoan bizi diren euskaldunek, komunitate desberdinetako euskaldunekin eta Euskal Herriarekin harremana eta komunikazioa izateko, batez ere, aldizkari, egunkari eta irrati programak egin dituzte. Aldizkarien artean izan dira Urazandi digitala bildumak biltzen dituenak, adibide batzuk: Buenos Airesen argitaratzen zen Laurac Bat (1878-1975), Los Angelesen California'ko Eskual Herria (1893-1897) edota Mexikoko Cancha (1945-1958). Urazandi digitalak biltzen dituen aldizkari gehienak ez daude jada aktibo. Orain, Euskal Etxe eta elkarte batzuek bidaltzen dituzten astekariak ( $\mathrm{NABO}^{3}$ ren Astero, adibidez), edota euskal etxe edo diasporako kideek daramatzaten irrati programak daude. Irrati programen adibide bi, La Platako euskal etxetik emititzen duten Raíces Vascas-Euskal Sustraiak eta Boiseko euskal komunitateko kideek daramaten Boiseko Taupada saioa.

\footnotetext{
3 North American Basque Organization.
} 
Irrati programa hauek Interneten bidez emititzen dira eta horrekin lotzen ditugu diasporako kideek sortutako blog euskal amerikarrak. Horien artean Hella Basque, Euskal Kazeta edota Buber's Basque Page (euskaraz sortutako lehen blog-a).

Analisian Euskalkultura.com-en zentratuko gara eta aztertuko da nolakoa izan zen diaspora hedabide honen sorrera eta eboluzioa; diaspora medio honek zelako erantzuna duen Estatu Batuetan bizi diren euskaldunen artean, irakurtzen duten edo ez; eta ze eratako albisteak diren medioak eman dituenak.

\subsection{DiAsporarekin ZEGOEN HUTSUNEA BETETZEN}

\subsubsection{Euskaletxeak ${ }^{4}$ aldizkaria}

Diasporako kideekin egindako sakoneko elkarrizketei esker ikusi dugu euskal diaspora eta jatorrizko herrialdearen arteko komunikazioa, beste hainbat diasporaren kasua den moduan, hasiera batean «etxetik» bidaltzen ziren gutunekin, harreman interpertsonalekin, jatorrizko herrialdera egindako bisitekin, egunkariekin edota, nazioarteko egunkariek Euskal Herriari buruz ematen zituzten albisteak irakurriz asetzen zela:

«My mother I remember she could start a letter and I don't remember how many months she could be to finish the letter. Telephone usually was bad experience, my brother once called me when I was in Oñate, an operator had to call off, my brother found a 300 dollar phone bill. So, we didn't call that much. You always have to make sure you cut down. Before that no...somebody will come and visit us every few years...» (Pertsona aktiboa Nevada eta Idahoko euskal komunitatean, komunikazio pertsonala, Boise, 2017 urteko martxoa)

«Before I used to read the New York Times, the World section because they always said something about the Basque Country. That was the closest I could get you. I remember also going to Mexican markets with my father on Sundays to find out the Athletic Club Scores. The Mexican newspapers put the scores.» (Pertsona aktiboa Idahoko euskal komunitatean, komunikazio pertsonala, Boise, 2017 urteko martxoa)

\footnotetext{
4 «Euskaletxeak» aldizkariak euskal diasporaren ekintzez eta honen egunerokotasunaz informatzen zuen. Bere orrien artean bai Euskal Herrian zein Euskal Herritik kanpo bizi ziren euskaldunei buruzko albisteak argitaratzen zituzten. Paperean argitaratzen zen eta Eusko Jaurlaritza zegoen honen atzean. (http://www.euskadi.eus/euskal-etxeak-magazine/web01-s1leheki/es/).
} 
Sakoneko elkarrizketa guztietan esan digute interneten etorrerak, Eusko Jaurlaritzak euskal etxeetan ordenagailuak jarri izanak eta Jaurlaritzan ingelesez hitz egiten zuen jendea jartzeak asko hobeto zuela komunikazioa eta etapa berri bat hasi zela ordutik aurrera Euskal Herriaren eta euskal diasporako kideen arteko komunikazio eta harremanean: "Now, with the internet is really easy to communicate with the family and friends. Facebook, myspace, e-mail, whatsap. We have a family group in whatsap, is fantastic!» (Boiseko Euskal museoko langilea, komunikazio pertsonala, Boise, 2017ko martxoa).

«I whatsapp. I only use watsapp with my Basque Friends in the Basque Country. With my Americans friend I use Imessage. I whatsapp with my izeko and my cousin at least, not daily, but 4 or 5 times a week. And if I wasn't too busy I would skype with them. My dad skypes with my izeko (his sister) every Tuesday. Every Tuesday and sometimes on the weekends too. The communication is very regular. Before it was neaely impossible.

My family $\mathrm{n}$ the BC had computer in 2008.» (Idaho eta Nevadako euskal komunitateko kide aktiboa, komunikazio pertsonala, Boise, 2017 urtek martxoa)

Baina momentu honetara iritsi arte ere, izan da komunikaziorik eta honen eboluzioa aztertuko da.

1989 urtean sortu zen Euskaletxeak aldizkaria, diasporako kideei bidaltzen zitzaien eta egun oraindik bidaltzen den aldizkaria da. 1982.urtean Garaikoetxearen Gobernuko Kultura Sailak Ameriketako Euskaldunak Euskadin Lehen Batzarra antolatu zuen Donostian irailaren 2tik 7ra. Ugalderen lanaren arabera, kongresu honetara 9 herrialdetako 203 ordezkari joan ziren (86 Argentinatik, 14 Venezuelatik, 9 Txiletik, 8 Estatu Batuetatik, 5 Uruguaitik, 4 Kanadatik, 3 Kolonbiatik, 3 Mexikotik, 2 Perutik eta begirale bat Filipinetatik (Ugalde, 2007: 135). Kongresu horretan euskal diasporako kideek euskal diasporarekin komunikatzeko aldizkari baten beharra zegoela esan zuten (Josu Legarreta, Kanpoan den euskal komunitate eta euskal etxeentzako zuzendari ohia, komunikazio pertsonala, 2017ko maiatza).

«Emplazar al Gobierno Vasco a la publicación de una revista mundial vasca, impresa en la propia Euzkadi, que contenga: información sobre Euzkadi, trabajos de cultura y actividad de los vascos en el exterior, material este último que será suministrado por las Federaciones y/o representantes autorizados de cada país.» (Legarreta eta Mignaburu 2016: 101)

Munduan zehar zeuden euskaldunek eskatu zutena kontutan izanda, komunikazio alorrean Euskal Herria eta euskal diaspora komunikatzeko aldizkari baten beharra zegoela ikusi zuten. Horrela hiru hilean behin etxeetara bidaltzen zen paperezko aldizkaria jarri zuten martxan. Aldizkari hori Euskal Etxeak aldizkaria izan 
zen, 1989.urtean sortu zen eta Euskal Herriaren eta euskal diasporaren inguruko albisteak ematen zituen.

Totoricaguenak bere doktorego tesian aldizkariari buruzko informazioa ematen du: «Journal published for the diaspora communities three or four times a year by the Basque Government with news and information regarding Euskal Herria and Basques from all over the world»; horrez gain, Totoricaguenak euskal identitatea diasporan nola mantentzen den aztertzen du eta horretarako Euskal Etxeak aldizkariaren garrantziari buruz galdetzen die diasporako kideei. Bere hitzetan ikusi daiteke zein garrantzitsua izan zen aldizkari honen sorrera komunitate batu eta diaspora antolatu baten sentimentua izateko (Totoricaguena, 2000: 217).

Legarretaren hitzetan aldizkaria etxean hartzeko interesa erakusten zuten guztiei bidaltzen zitzaien eta 2011 urtetik aurrera sareko formatura pasatu eta ostiral guztietan bidaltzen den newsletter batean bihurtu da (Josu Legarreta, Kanpoan den euskal komunitatearentzako zuzendari ohia, komunikazio pertsonala, 2017ko maiatza).

\subsubsection{Euskalkultura: diaspora medio baten bila}

1998 urtean, Kulturaren Aldeko Euskal Fundazioak pentsatu zuen beharrezkoa zela diasporarekin harremana eta komunikazioa mantentzeko zerbait gehiago egitea. Horrela Euskalkultura sortzea erabaki zuten eta Joseba Etxarri kazetaria jarri zuten honen atzean. Etxarri bazen garairako diaspora gaietan aditu eta baita aritua, atzerrian igarotako urteek emandako jakinduria eta esperientziak diaspora gaiak jorratzeko abilezia nahiko eman zioten. Bere hitzetan:

«Aurten dira 30 urte daramazkidala diasporarekin harremanetan. Hasi nintzan Estatu Batuetan eta Estatu Batuetan euskaldunak zeuden bazter guztiak pateatu nituen. Normalean, orduan, diasporari buruz ezer gutxi zegoen. 1988an bazegoen MUGA izeneko aldizkari bat (Deiaren ingurukoa), hor publikatu zidaten elkarrizketa bat Pete Cenarrusarekin ${ }^{5}$ eta ni hasi nintzen pixkat interesatzen. Hasi nintzen hainbat elkarrizketa eta artikulu egiten. Nik lan egiten nuen Eguna astekarian. Hor publikatu nituen hainbat gauza, eta hasi nintzan urtero nire oporrak horretara dedikatzen. [...] 90ean, urte hasieran bidai bat egin nuen eta gero 6 hilabete eman nituen Estatu Batuetan, Kalifornian. [...] Gero liburua etorri zen 1994an «Euskaldunen Amerika». Ordurako erakusketa bat zabaldu nuen Donostian

\footnotetext{
5 Pete Cenarrusa euskal amerikarra Idahoko Estatu Idazkaria izan da 1967 urtetik 2003ra. Bere familia Bizkaiakoa zen eta beti mantendu izan du harreman estua Euskal Herriarekin eta honekin zerikusia duten gaiekin.
} 
diasporari buruz: «IparAmeriketako Euskal Herria». Hor azaltzen nuen dena. Renora eraman genuen 1999en Euskal Aste Nagusia antolatu genuenean. Wyoming-eko Buffalon KBBs i omenaldia egin genion eta han ere. [...] Argentinako ia Euskal etxe guztietan hitzaldiak eman ditut, bisita asko egin ditut.» (Joseba Etxarri, Euskalkultura.com-eko zuzendaria, komunikazio pertsonala, 2017urteko urria)

1998 urtean buletina Santiago de Txilen argitaratzen zen, ondoren Argentina, Uruguai, Venezuela, Panama, Puerto Rico, Mexiko eta Estatu Batuetara zabaldu zen. 2001 urtean, Euskalkulturak digitalera eman zuen saltoa eta Euskalkultura.com sortu zen. Buletinak bi atal ditu, berriak eta agenda, eta egunero bidaltzen da.

Etxarriren hitzetan, Euskalkultura.com diaspora hedabide bat baino gehiago da, eta diasporaren aldeko bulego bat direla dio. Nahiz eta lan gehien ematen diena Euskalkultura.com izan, horrez gain beste hainbat gauza egiten dituzte, adibidez, hitzaldiak, mahainguruak eta hitzaurreak antolatzen dituzte eta dibulgaziorako lanak egiten dituzte, adibidez, urte mordoa daramate Baionako Herria astekarian Euskal diasporari buruz idazten.

\subsubsection{Aro digitala ate joka}

2001ean interneterako jausia eman zuten eta hor hasi zen aldizkari moduan baina Euskal Fundazioaren webgunearen barruan. Webgunean honela azaltzen duten euren burua: «Euskalkultura.com euskal diaspora eta kulturaz espezializatutako buletin eta webgunea da, Euskal Herriaren eta munduan barreiatutako euskal komunitateen arteko zubi-lana egitearren Basque Heritage Elkartea izeneko irabaziasmorik gabeko elkarteak sortu eta garatua».

Euskalkultura.com-ek munduan zehar dauden euskaldunei buruzko albisteak zabaltzen ditu eta, zuzendariak elkarrizketan azaldu zuen bezala, albiste horiek lortu eta garatzeko bi korrespontsal dituzte, bat Estatu Batuetan (Renon) eta bestea Argentinan (Buenos Airesen). Iturriei dagokionez, euskal etxeetatik bidaltzen duten informazioa daukate baita ere, hainbat elkarte eta erakundek bidaltzen dietena (NABO, Etxepare Euskal Institutua, Eusko Jaurlaritzako Kanpo Harremanetarako Idazkaritza Nagusia) eta beste egunkari batzuk argitaratzen dituzten eta interesgarriak direla uste dituzten albisteak.

Hizkuntzari dagokionez, Euskalkultura.com-ek, irakurleen beharrizanak erantzuteko, albisteak hiru hizkuntzatan banatzen ditu: euskara, ingelesa eta gaztelera.. Bestalde, eurek ere beste batzuentzako iturri direla dio: «Atzo idatzi zidan Rosarioko batek apuratuta Palabra de Vasco irrati programa egiten dutela astero eta buletin barik ezin dutela egin» (Etxarri, Euskalkultura.com-eko zuzendaria, komunikazio pertsonala, 2017ko X). 
Euskalkultura.com-ek 2009 urtean egin zuen Facebook-era saltoa eta egun 9.739 (2018urteko azaroan) jarraitzaile dauzka. Bere lehen orrialdean, batez ere, Euskalkultura.com-eko albisteak elkarbanatzen dituzte. Arduradunak dioen moduan, ez daukate denbora askorik Facebook-eri dedikatzeko eta, hori dela eta, nahikoa abandonatuta dute eta izan ahalko zituzten baino jarraitzaile gutxiago dauzkate. 2018 urteko urria-azaroan euren Facebook orrialdean eta hainbat euskal etxeetako orrialdetan sare sozialekin laguntzeko bolondres baten bila zeudela argitaratu zuten Euskalkultura.com-eko arduradunek. Instagram-eri dagokionez, ez dute argazkietan oinarritutako sare sozial hau erabiltzen baina uste dute badela momentua pertsona bat eurekin lanean hasi eta sare sozialen ardura izateko.

\subsection{Audientziari Begira}

Medioko zuzendariak emandako datuen arabera, 5.500 dira Euskalkultura. com-ek egun dituen harpidedunak. Harpidedun horiek egunero Euskalkultura. com-ek bidaltzen duen buletina jasotzen dute. Buletin horretan hiru edo lau albiste zabaltzen dira euskal diasporari buruz edo honekin zerikusia duten gaiei buruz. Horrez gain, egongo diren ekitaldien agenda eta Euskalkultura.com-eko blog atalean dauden artikuluak argitaratzen dira. Estatu Batuetan bizi diren euskaldunen artean Euskal Herriarekin komunikatzeko dituzten ohituren inkesta zabaldu genuen 2018 urteko maiatzean. Lortutako erantzunei esker ikusi ahal izan dugu zein den Estatu Batuetan bizi diren diasporako kideek egiten duten Euskalkultura.com-en kontsumoa:

\section{口EZ 口BAI}

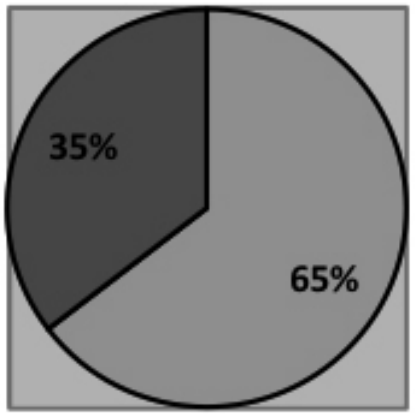

Iturria: autoreak egina inkestako emaitzekin.

1. IRUDIA

Euskalkultura.com-en kontsumoa AEBtan 
Egindako inkestaren emaitzetan ikusi dezakegu Estatu Batuetan bizi diren euskaldunen eta inkesta erantzun dutenen \%35,4ak kontsumitzen duela Euskalkultura.com.

\subsection{Diaspora Albisteak: Kultura eta Zer gehiago?}

Euskalkultura.com-ek ematen dituen albisteak ze eratarakoak diren ezagutu al izateko albisteen analisia egin da. Albiste horiek bi taldetan banatu ditugu (gaia eta protagonista) eta gero bi talde horiek azpitaldetan. Analisia 2015 urtetik 2018 urtera egin da. Ikusi nahi izan dugu zein gai den nabariena Euskalkultura.com-en eta gai horien garrantzia aldatzen joan den lau urte hauetan. 2015 urtean, kultura eta euskal etxeekin zerikusia duten albisteak dira nabarienak. Kulturaren gaia zabala da eta, bere barne beste kategorizazio bat egin dugu eta ondorengo azpitaldetan banandu dugu: literatura eta artea, dantza eta musika, euskara, kirola, sukaldaritza eta mus-a.

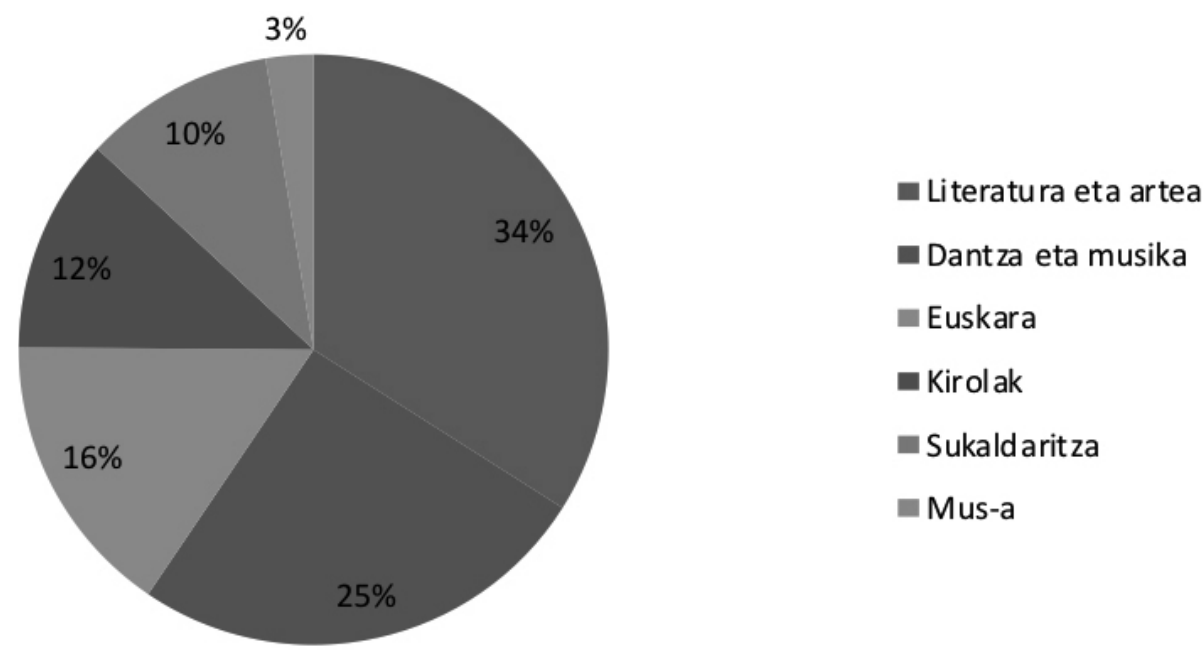

Iturria: autoreak egina.

2. IRUDIA

Kulturaren barruan dauden gaiak

Literatura eta artearen inguruko gaiak dira aipagarrienak, horien artean, adibidez, euskal film laburren emanaldia Mexikon, euskal gaiei buruzko argitalpenak eta «Artea eta Euskal diaspora» bezalako emanaldiak.

Horrez gain, euskal diasporako kideen eta Euskal Herriaren arteko harremanei buruzko albiste ugari ere daude, baita euskal diasporako kideak bizi diren herrialde 
horietako gizartearekin dituzten harremanei buruz. Albiste hauek «harreman» edo networking taldearen barruan sartu ditugu. Hezkuntza eta Jaialdiei buruzko albisteak ere hainbat izan dira. Hezkuntzaren atalean daude unibertsitate mailan edo euskal etxeetan emandako aurkezpenak, kasurako. Jaialdiak ere oso garrantzitsuak dira kanpoan bizi diren euskaldunentzako, bai komunitatea sortzerakoan, bai identitatea mantentzerakoan; beraz, normala da horren inguruko albisteak ematea. Gainera, nabarmendu behar da, 2015 urtean bost urtean behin antolatzen den Boiseko Jaialdia antolatu zela, eta horren inguruko albisteak ugari izan zirela.

2016 urteko analisian, datuak 2015 urtekoaren oso antzekoak dira. Desberdintasun bakarra izan daiteke, kulturarekin zerikusia duten albisteen kopurua altuagoa dela, eta harremanena baxuagoa. Urte honetan ere, «literatura eta artea» eta "dantza eta musika» azpitaldeak dira nabarienak kultura sailean.

2017 urtean, berriro ere kultura eta euskal etxeei buruzko gaiak dira portzentaje handiena betetzen dutenak. Oraingoan euskal etxeen gaiak dira gehienak. 2017 urtean bai ikusi ahal izan dugu, kultura atalaren azpian jarri ditugun gaien artean Euskararen gaiarekin lotutako albisteak gorakada izan dutela. 2015 eta 2016 urteetan euskararekin lotutako gaiek \%3 eta \%4a ziren eta 2017 urtean \%10. Jaitsiera bat dago hezkuntzarekin zerikusia duten albisteetan.

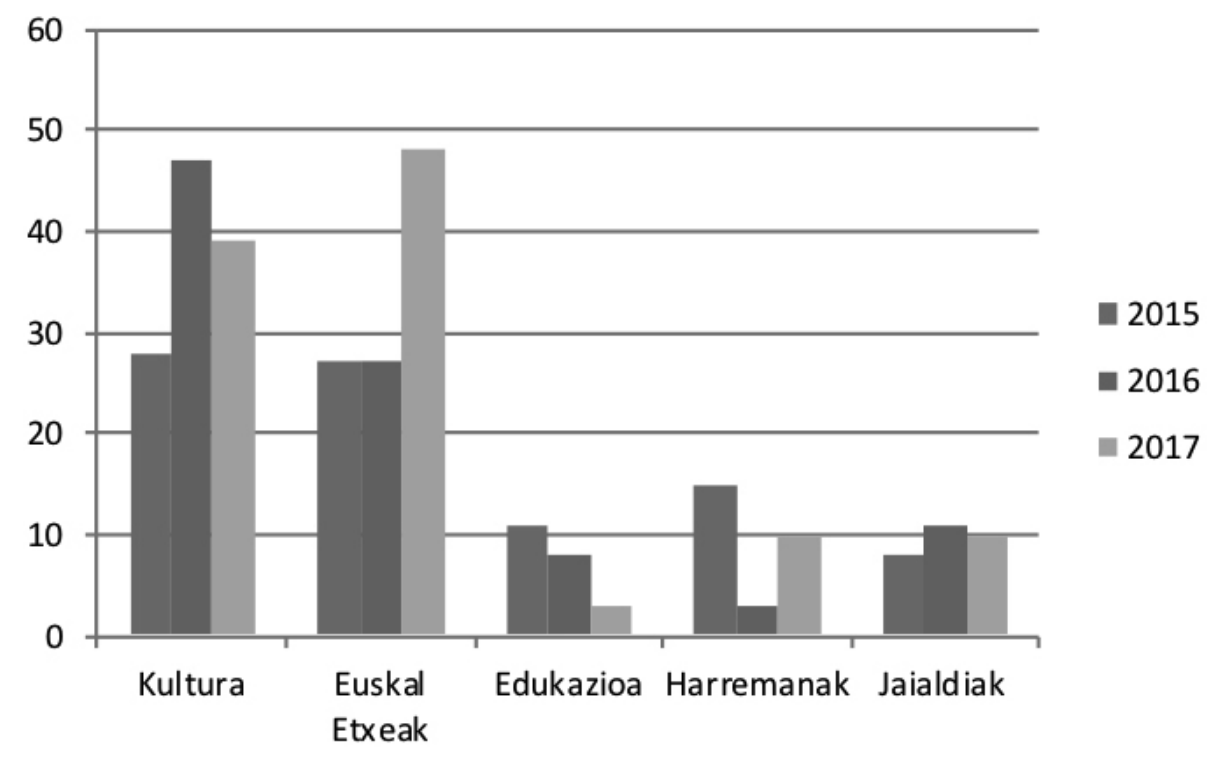

Iturri: autoreek egina.

\section{IRUDIA}

Euskalkultura.com-ek gehien publikatu dituen albisteen datuan 2015, 2016 eta 2017 urteetan 
Amaitzeko, 2018 urtean, aurreko hiru urteekin jarraituz, kultura eta euskal etxeen gaiak dira nabarienak, eta igoera ikusi dugu Euskal Herria eta Euskal diaspora eta Euskal diaspora eta bizi diren herriekin dituzten harremanei buruzko albisteetan. Bestalde, denak jarraitzen du antzerako.

Orokorrean, kultura eta euskal etxeei buruzko albisteak dira nabarienak desberdintasun handiarekin. Gai horien ondoren, hezkuntza, jaialdiak eta harremanei buruzkoak eta, ikusten da, azken urtean igoera bat egon dela Euskal Herria eta kanpoan bizi diren euskaldunen harremanei buruzko albisteetan baita hezkuntzari buruzko albisteetan ere.

Gaiak ezagutzeaz gain, jakin nahi izan dugu, baita ere, nortzuk diren albisteetako protagonistak. Izan ere, diaspora medio bat izanik, normalena da protagonistak diasporako kideak izatea, baina, askotan, euren jatorrizko herrialdeari buruzko informazioa ere izan nahi dute. Beraz, interesgarria egiten zitzaigun datu horiek aztertzea.

Albiste gehienak euskal diasporako kideei buruz idatzitakoak dira. Normala den moduan, hori da eta diaspora hedabide baten eginbeharra. Hala ere, desberdintasun asko dago diasporako kideei buruzko albiste eta Euskal Herria protagonista duten albisteen artean. Diasporako jendeari buruz idatzitako albisteak albisteen \%83 diren bitartean, Euskal Herrikoei buruzkoak \%25 dira.

Inkestako erantzunei esker Estatu Batuetan bizi eta Euskalkultura.com kontsumitzen duten kopuruak ezagutzera hurbildu gara eta analisiak esan digu ze eratako albisteak argitaratzen diren. Horrez gain, jakin nahi izan dugu, zein esparru hobetzea gustatuko litzaieken Estatu Batuetan dauden euskaldunei Euskal Herriaren eta kanpoan diren euskaldunen artean dagoen harremanean.

2018 urtean zabaldutako inkestan ikusi ahal izan dugu, nahiz eta kultura $(\% 25,9)$ izan diasporako kideei gehien interesatzen zaien gaia, badaudela hainbat, batez ere, hezkuntza $(\% 23,6)$ eta arlo enpresarialaren $(\% 9,5)$ inguruko gaiei buruzko informazioa nahi dutenak. Hezkuntzari buruz ezagutu nahi duten informazioak lotura du truke programekin, ikastaroekin, atzerriko unibertsitate baten ikasi eta gero hori nola baloratuko den Euskal Herrian lana bilatzerakoan, Estatu Batuetako unibertsitateetako matrikulak ordaintzeko laguntzak, Estatu Batuetako unibertsitate eta Euskal Herriko Unibertsitateen arteko irakasgai konbalidazioak etab.

Enpresarekin lotutako gaiak izango dira, adibidez, zein eratako langileak bilatzen dituzten Euskal Herriko enpresak (Bizkaia Talent ${ }^{6}$-ek egiten duen lanaren

\footnotetext{
${ }^{6}$ Bizkaiko Foru Aldundiaren Sustapen Ekonomikorako Sailak bultzatuta eratu zen bizkaia: talent 2005. urtean, irabazi asmorik gabeko elkarte izaeradun ekimen bezala, misio argi batekin: Bilbao, Bizkaiko
} 
antzekoa) edota harremanik egin daitekeen Euskal Herriko enpresa eta orain bizi diren herrialdeetakoen artean. Galdera horren ondoren, aukera ematen genien «beste batzuk» gehitzeko, eta hor, 21 erantzun izan genituen. Horietatik 5 erantzunek berriro ere hezkuntza esaten zuten eta hiruk hizkuntza. Hizkuntzarekin euskara ikastaroak, liburuak eta hauei buruzko informazioa eskatzen zuten. Euskara ikastaroak daude Estatu Batuetako hainbat leku eta euskal etxetan baina ikusi dugu badaudela horietatik kanpo gelditzen direnak eta hizkuntza ikasi nahi dutenak. Horrekin lotuta inkesta amaieran ondorengoa gehitu zuten batzuk:

«I wish there more online courses for learning the Basque language. Online courses I found were okay for beginners, but none were stellar. Becoming fluent via online courses seems almost impossible.» (Inkestako erantzuna, anonimoa)

«There needs to be more tools for learning Basque remotely specially for those of us living abroad.» (Inkestako erantzuna, anonimoa)

«I feel like my biggest disconnect from my Basque heritage is my poor Basque language skills. I am very active in my local club, but I wish there were classes offered closer to learn.» (Inkestako erantzuna, anonimoa)

«I would love for more connections and opportunities regarding language.» (Inkestako erantzuna, anonimoa)

Beste bost erantzunek arlo enpresariala eta politikoa garatzea beharrezkoa zela zioten: "Nere ustez, politika apur bat gehiago hemengo jenteak pixka bat gehiago ulertzeko zer gertatzen dan Euskal Herrian eta baita ere enpresa giroan hartu emana edukitea» (Inkestako erantzuna, anonimoa). Amaitzeko beste erantzunek kirola eta kultura garatu behar zirela zioten.

\section{Konklusioak}

Analisiari esker ezagutu ahal izan dugu zein izan den Euskalkultura.com-en sorrera eta honen eboluzioa eta honek zabaltzen dituen albiste gehienak kulturaren ingurukoak direla. Hedabidearen izena kontuan hartzen badugu, zenbaki horrek zentzua dauka, eta gainera, inkestaren emaitzek erakutsi digute gai hori dela, batez ere, kanpoan bizi diren euskaldunei gehien interesatzen zaiena. Hala ere, inkesta berdin horrek erakutsi digu hezkuntzarekiko dagoen interesa ere oso altua dela

\footnotetext{
lurralde historikoa ta Euskadin orokorrean, berrikuntza eta ezagutzaren prozesura oso ondo prestatutako pertsonak erakartzeko, lotzeko eta eusteko beharrezko baldintzen ezarpena bultzatzea eta laguntzea. Bizkaia Talent-eko webgunetik hartutako informazioa: https://www.bizkaiatalent.eus/eu/?cl=1
} 
$(\% 23,5)$, ia kulturarena beste $(\% 26)$. Bestalde, nahiz eta portzentaje ez oso handia izan $(\% 9,5)$, esparru ekonomikoarekiko ere interesa dago.

Georgiouk (2005) dio diaspora medioak medio bat baino gehiago direla eta hainbat autorek (Yin,2013; Johnson, 2000; Jeffres, 1999; Zhand eta Hao, 1999) azpimarratzen dute horrez gain, diaspora medioek identitatea indartzeko eta azpitaldeak batzeko balio dutela. Bat dator planteamendu horrekin Euskalkultura. com-eko zuzendaria eta beraien lana ere diaspora medio batetik haratago doala dio: "Gehiago gara diasporaren aldeko bulego bat. Egia da, lan gehien ematen diguna euskalkultura dela, baina horrekin batera beste hainbat gauza ere egiten ditugu. Hainbat jendek deitzen digu laguntza eske» (Joseba Etxarri, Euskalkultura.com-eko zuzendaria, komunikazio pertsonala, 2017 urteko urria). Egiten dituzten gauza horien artean: hitzaldiak, mahai-inguruak, hitzaurreak, artikuluak, eta Euskal diasporari buruzko argitalpenak daude.

Horrez gain, hainbat dira informazio edo laguntza eske eurengana jotzen dutenak eta aholkuak ere banatzen dituzte kanpotik Euskal Herrira etorri nahi duten euskaldunentzat zein Euskal Herritik atzerrira joan nahi dutenentzat. Beraz, hiru hizkuntzatan argitaratzeaz gain, Euskalkultura.com-ek autore desberdinek diaspora medioei esleitzen dizkieten beste funtzioak ere betetzen dituela baieztatu daiteke.

Azkenik, azpimarragarria da Euskalkultura.com-ek euskal diaspora oinarri moduan duen informazioa lantzen duela, euskal diasporara zuzendua, bereziki. Baina, azken bi urteetan, diasporaren inguruko gaiek gero eta presentzia nabariagoa dute Euskal Herriko medioetan. Eusko Jaurlaritzak Euskal Diasporaren Eguna ospatu zuen 2018 urteko irailaren 8an eta Urkullu Lehendakari lehen aldiz Argentinako Euskal Aste Nazionalean izan da. Horrek eragina izan du komunikabideetan. Horrez gain, diasporako kideak protagonistak diren hainbat telesail daude martxan (Euskalonski, Vascos por el Mundo, Origen, Bai Bagara). Beraz, baieztatu daiteke euskal diasporaren gaia agenda publikoan sartzen ari dela. Etorkizunera begira, aztertzekoa da zein izango den fenomeno honen eboluzioa eta zein paper jokatuko duen testuinguru honetan Euskalkultura.com-ek.

\section{Bibliografia}

Alonso, A., \& Oiarzabal, P. J. (Eds.). (2010). Diasporas in the new media age: Identity, politics, and community. Reno: University of Nevada Press.

Amezaga Albizu, J. (2004). Satelite bidezko nortasunak: Latinoamerikan Canal Vasco ikusten. Donostia: Utriusque Vasconiae. 
Ancien, D., Boyle, M., \& Kitchin, R. (2009). Exploring diaspora strategies: An international comparison. Report on an International workshop.

Ben-Rafael, E. (2013). Diaspora. Current sociology, 61(5-6), 842-861.

Bozdag, C., Hepp, A., \& Suna, L. (2012). Diasporic media as the «focus» of communicative networking among migrants. En Rigoni, I., \& Saitta, E. (Eds.) Mediating cultural diversity in a globalized public space (pp. 96-115). London: Palgrave Macmillan.

Brubaker, R. (2005). The «diaspora» diaspora. Ethnic and racial studies, 28(1), 1-19.

Cohen, R. (1996). Diasporas and the nation-state: from victims to challengers. International affairs, 72(3), 507-520.

Cohen, R. (2007). Creolization and Diaspora: The Cultural Politics of Divergence and Some Convergence. Opportunity Structures in Diaspora Relations: Comparisons in Contemporary Multi-Level Politics of Diaspora and Transnational Identity, 85-112.

Fazal, S., \& Tsagarousianou, R. (2002). Diasporic communication: Transnational cultural practices and communicative spaces. Javnost-The Public, 9(1), 5-18.

Georgiou, M. (2005). Diasporic media across Europe: multicultural societies and the universalism-particularism continuum. Journal of ethnic and migration studies, 31(3), 481-498.

Goirizelaia, M., \& Iturregui, L. (2018). From cultural showcases to public diplomacy agents: Basque-American festivals in the United States. Diaspora Studies, 1-17.

Karim, K. H. (2003). The media of diaspora. New York: Routledge.

Lee, H. M. (1938). The Problem of the Third Generation Immigrant. Rock Island: Printers and Blinders.

Leurs, K., \& Ponzanesi, S. (2014). Intersectionality, digital identities and migrant youths. The Routledge companion to media and gender, 632-642.

Naficy, H. (2003). Narrowcasting in diaspora: Middle Eastern television in Los Angeles. En Karim, The media of diaspora (pp. 64-75). New York: Routledge.

Navaz, L. S., \& Ferrer, A. F. (2012). Migrant Minority Media: Towards a Democratization of the Western Mediascape?. En Rigoni, I., \& Saitta, E. (Eds.) Mediating Cultural Diversity in a Globalized Public Space (pp. 76-95). London: Palgrave Macmillan.

Newland, K., \& Plaza, S. (2013). What we know about diasporas and economic development. Migration Policy Institute, 5, 1-13.

Ogunyemi, O. (2015). Journalism, audiences and diaspora. London: Palgrave Macmillan.

Peñafiel, Carmen; Casado, Miguel Ángel; Fernandez de Arroyabe, Ainhoa; Gómez, Leire; (2008). "Made in Galeusca": canales internacionales de TV autonómicos, exportadores de identidad; Anàlisi: quaderns de comunicació i cultura, (37), 69-92.

Retis, J. (2014). Inmigrantes territoriales/inmigrantes digitales: latinoamericanos en contextos diaspóricos. Comunicación e industria digital, Universidad de Lima, Lima.

Safran, W. (1991). Diasporas in modern societies: Myths of homeland and return. Diaspora: A journal of transnational studies, 1(1), 83-99.

Sheffer, G. (2003). Diaspora politics: At home abroad. Cambridge: Cambridge University Press. 
Sinclair, C., \& Smets, K. (2014). Media freedoms and covert diplomacy: Turkey challenges Europe over Kurdish broadcasts. Global Media and Communication, 10(3), 319-331.

Smets, K., Meers, P., Winkel, R. V., \& Van Bauwel, S. (2011). A semi-public diasporic space: Turkish film screenings in Belgium. Communications, 36(4), 395-414.

Totoricaguena, G. P. (2000). Comparing the Basque diaspora: Ethnonationalism, transnationalism and identity maintenance in Argentina, Australia, Belgium, Peru, the United States of America, and Uruguay (Doctoral dissertation, London School of Economics and Political Science (United Kingdom)).

Vecino, L. E., Ferrer, A. F., \& Dallemagne, G. (2015). Discursive Inclusion and Hegemony: The Politics of Representation in Spanish Migrant Minority Media. In Ogunyemi, Journalism, Audiences and Diaspora (pp. 87-103). London:Palgrave Macmillan. 